\title{
Tat-DJ-1 inhibits oxidative stress-mediated RINm5F cell death through suppression of NF- $\kappa$ B and MAPK activation
}

\author{
Hyo Sang Jo ${ }^{1} \cdot$ Hyun Ju Cha ${ }^{1} \cdot$ Sang Jin Kim ${ }^{1} \cdot$ Hyeon Ji Yeo ${ }^{1} \cdot$ Su Bin Cho ${ }^{1}$ • \\ Jung Hwan Park ${ }^{1}$ Chi Hern Lee ${ }^{1}$ Eun Ji Yeo ${ }^{1}$ Yeon Joo Choi ${ }^{1}$ - Won Sik Eum ${ }^{1}$. \\ Soo Young Choi $^{1}$
}

Received: 5 April 2016 / Accepted: 22 July 2016 / Published online: 9 August 2016

(C) Springer Science+Business Media New York 2016

\begin{abstract}
Oxidative stress is highly involved in the development of diabetes mellitus by destruction of pancreatic $\beta$-cells. DJ-1 is an antioxidant protein and DJ-1 expression levels are known to be reduced in diabetes mellitus. Thus, we examined the effects of DJ-1 protein against oxidative stress-induced pancreatic $\beta$-cell (RINm5F) death using cell permeable wild-type and mutant-type (C106A) Tat-DJ-1 proteins, which both efficiently transduced into RINm5F cells. Intracellular stability of wild-type Tat-DJ-1 persisted two times longer than C106A Tat-DJ-1. Wild-type Tat-DJ-1 protein markedly protected cells from hydrogen peroxideinduced toxicities such as cell death, reactive oxygen species generation, and DNA fragmentation. Further, wild-type Tat-DJ-1 protein significantly inhibited hydrogen peroxideinduced activation of mitogen-activated protein kinases and $\mathrm{NF}-\mathrm{\kappa B}$ signaling. On the other hand, C106A Tat-DJ-1 protein did not show the same protective effects. These results indicate that wild-type Tat-DJ-1 inhibits oxidative stress-induced cellular toxicity and activation of mitogenactivated protein kinases and NF- $\mathrm{KB}$ signals in RINm5F cells. These results suggest that wild-type Tat-DJ-1 protein may be a potential therapeutic agent against diabetes mellitus or toward the prevention of pancreatic $\beta$-cell destruction.
\end{abstract}

Hyo Sang Jo and Hyun Ju Cha have contributed equally to this work.

Won Sik Eum

wseum@hallym.ac.kr

$\triangle$ Soo Young Choi

sychoi@ hallym.ac.kr

1 Department of Biomedical Science and Research Institute of Bioscience and Biotechnology, Hallym University, Chuncheon 24252, Korea
Keywords WT Tat-DJ-1 $\cdot$ Mutant DJ-1 - Oxidative stress · Cytotoxicity $\cdot$ Protein therapy

\section{Introduction}

Oxidative stress-induced cellular reactive oxygen species (ROS) are highly associated with pancreatic $\beta$-cell death, since antioxidant protein expression levels are very low in pancreatic $\beta$-cells which leaves them more susceptible to ROS in comparison to other tissues (Lenzen et al., 1996; Suarez-Pinzon et al., 1997; Tabatabaie et al., 2003). Other studies have demonstrated that increased cellular ROS levels lead to pancreatic $\beta$-cell destruction, while overexpressed antioxidant proteins inhibit oxidative stressinduced pancreatic $\beta$-cell death (Hohmeier et al., 1998; Tiedge et al., 1998; Tiedge et al., 1999; Lee et al., 2015). In a previous study, we demonstrated that antioxidant proteins transduce into pancreatic $\beta$-cells where they deliver a significant protective effect against oxidative stress-induced pancreatic $\beta$-cell death. Delivery of proteins into cells was achieved using protein transduction domains (PTDs), which, when fused with therapeutic proteins, can deliver those proteins into cells (Kim et al., 2013; Lee et al., 2015). These studies suggest that the regulation of ROS production plays a crucial role against oxidative stress-induced pancreatic $\beta$-cell death. In addition, several studies including those by our group have shown that PTD fusion proteins transduced into various cells and prevent oxidative stressinduced cell death (Wadia and Dowdy, 2002; Kubo et al., 2008; Dietz, 2010; van den Berg and Dowdy, 2011; Zhang et al., 2014; Kim et al., 2015a, b). Among the PTDs, Tat PTD is a short peptide consisting of 11 basic amino acids. Tat PTD have widely been used to deliver therapeutic 
proteins into a variety cells (Fawell et al., 1994; Koren and Torchilin, 2012; Jay and Lee, 2013).

DJ-1 is a homodimeric protein, belonging to the Thi/Pfp1 superfamily and is abundant in most living things from humans to bacteria (Bonifati et al., 2003). The results of other studies suggest that DJ-1 protein may have an antioxidant function by protecting against oxidative stressinduced neuronal cell death (Shendelman et al., 2004; Taira et al., 2004). However, DJ-1 mutations are known to cause autosomal-recessive hereditary Parkinson disease (Bonifati et al., 2003). The antioxidant function of DJ-1 protein depends on its cysteine residues (C46, C53, and C106). Among these cysteine residues, $\mathrm{C} 106$ is well characterized by being the most sensitive to oxidative stress and its mutation leads to loss of antioxidant function (Kinumi et al., 2004). Although several studies have shown that DJ-1 has neuroprotective effects against neuronal diseases (Aleyasin et al., 2007; Yanagida et al., 2009), there has been little study of the role the DJ-1 protein plays against oxidative stress-induced pancreatic $\beta$-cell death.

In this study, we prepared both cell permeable wild-type (WT) and mutant-type (C106A) Tat-DJ-1 proteins to examine the effects of DJ-1 protein against oxidative stressinduced pancreatic $\beta$-cell (RINm5F) death. Our results show that WT Tat-DJ-1 protein significantly protected against oxidative stress-induced pancreatic $\beta$-cell death, while C106A Tat-DJ-1 protein did not show the same protective effects. These results suggest a potential role as a therapeutic agent against pancreatic $\beta$-cell death for WT Tat-DJ1 protein.

\section{Results and discussion}

Several studies have shown that WT DJ-1 protein plays an important role in neuronal cell survival as an antioxidant protein in Parkinson's disease. However, mutant DJ-1 protein is highly associated with one of the risk factors and onset of PD (Bonifati et al., 2003; Kinumi et al., 2004; Shendelman et al., 2004; Taira et al., 2004). Although several studies have demonstrated that DJ-1 protein plays important roles in neuronal cell survival, the functions of WT DJ-1 and mutant C106A DJ-1 are not fully understood in pancreatic $\beta$-cells. Since antioxidant protein expression levels are very low in pancreatic $\beta$-cells, antioxidant proteins are considered to be potential therapeutic agents for pancreatic $\beta$-cell survival. Numerous studies have revealed that therapeutic proteins, when fused with PTDs, transduce into various cells and prevent against oxidative stressinduced cell death in vitro and in vivo (Wadia and Dowdy, 2002; Kubo et al., 2008; Dietz, 2010; van den Berg and Dowdy, 2011; Zhang et al., 2014; Kim et al., 2015a, b). We have also demonstrated that Tat-GLO protein protects against SNP-induced pancreatic cell death in a previous study (Kim et al., 2013). Thus, we prepared cell permeable WT and mutant-type (C106A) Tat-DJ-1 proteins in order to examine the effects of Tat-DJ-1 proteins on pancreatic RINm5F cells. We constructed a Tat-DJ-1 plasmid (Fig. 1a), which contained human DJ-1 complementary DNA (cDNA) (WT and C106A), Tat peptide, and 6His, while we also constructed control DJ-1 plasmid without Tat peptides. These DJ-1 proteins were overexpressed in E. coli and purified using Ni-NTA and PD-10 affinity chromatography. Purified proteins were confirmed by SDS-PAGE and Western blotting analysis (Figs. 1b, c).

To assess the levels of transduced Tat-DJ-1 proteins in RINm5F cells, cells were treated with various concentrations of WT and C106A Tat-DJ-1 proteins $(1-3 \mu \mathrm{M})$ for $1 \mathrm{~h}$ or treated with WT and C106A Tat-DJ-1 protein $(3 \mu \mathrm{M})$ for a range of times (10-60 min) after which transduced TatDJ-1 protein levels were determined by Western blotting. As shown in Fig. 2, WT and C106A Tat-DJ-1 proteins transduced into RINm5F cells time and concentration dependently. In contrast, control DJ-1 protein did not show the same transduction levels in the cells.

We examined the intracellular stability of transduced WT and C106A Tat-DJ-1 proteins in RINm5F cells. Significant levels of transduced WT Tat-DJ-1 protein persisted in the cells for $24 \mathrm{~h}$, compared to C106A Tat-DJ-1 protein, which was markedly reduced, persisting in the cells for $6 \mathrm{~h}$ (Fig. 3a). Using fluorescence staining, we also determined the intracellular stability of transduced WT and C106A TatDJ-1 proteins under same experimental conditions. Fluorescence signals show similar patterns to those of Western blot data (Figs. 3b, c).

In addition, we confirmed the transduction of Tat-DJ-1 protein in RINm5F cells using immunofluorescence staining. As shown in Fig. 4a, immunofluorescence signals strongly detected in Tat-DJ-1 protein-treated cells. However, immunofluorescence signals were not detected in control or control DJ-1 or Tat peptide-treated cells.

Several studies have demonstrated that ROS play a crucial role in pancreatic $\beta$-cell death. Since pancreatic $\beta$ cells contain very low levels of antioxidant proteins, pancreatic $\beta$-cells are more susceptible to oxidative stress (Lenzen et al., 1996; Suarez-Pinzon et al., 1997; Tabatabaie et al., 2003). We examined the potential effects of Tat-DJ-1 protein against oxidative stress-induced RINm5F cell death using a 3-(4,5-dimethylthiazol-2-yl)-2,5-dipheyltetrazolium bromide (MTT) assay. Figure 4b shows how transduced WT Tat-DJ-1 protein significantly increased cell viability against oxidative stress-induced cell death compared to the cells treated with hydrogen peroxide $\left(\mathrm{H}_{2} \mathrm{O}_{2}\right)$ only. In contrast, C106A Tat-DJ-1 protein did not affect cell viability compared to $\mathrm{H}_{2} \mathrm{O}_{2}$-treated cells or control DJ-1 protein-treated cells. In agreement with our results, other 
a
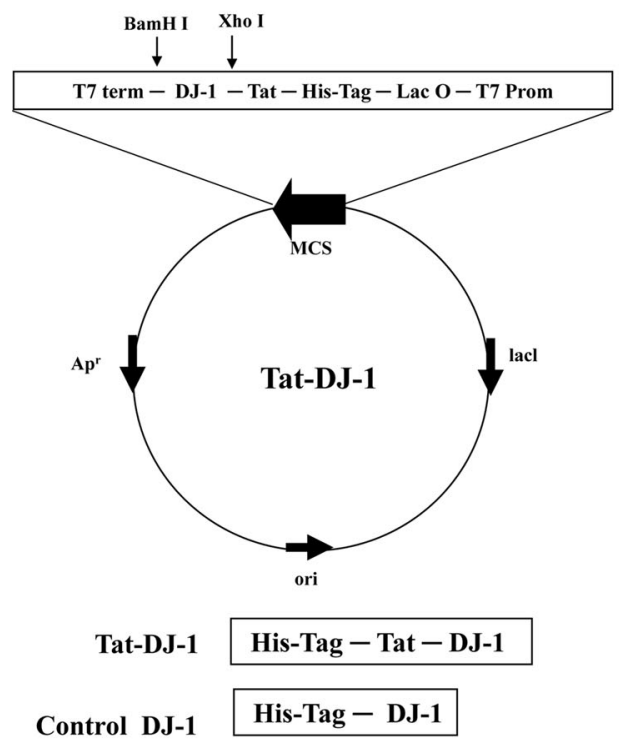

b

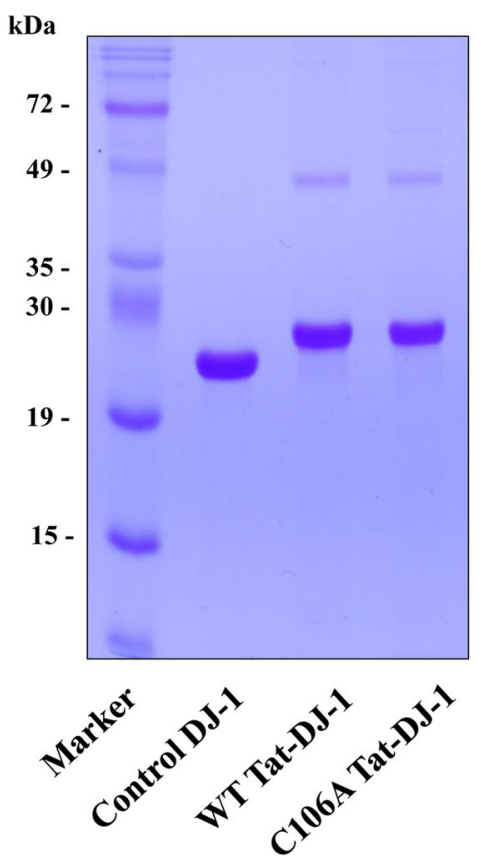

c

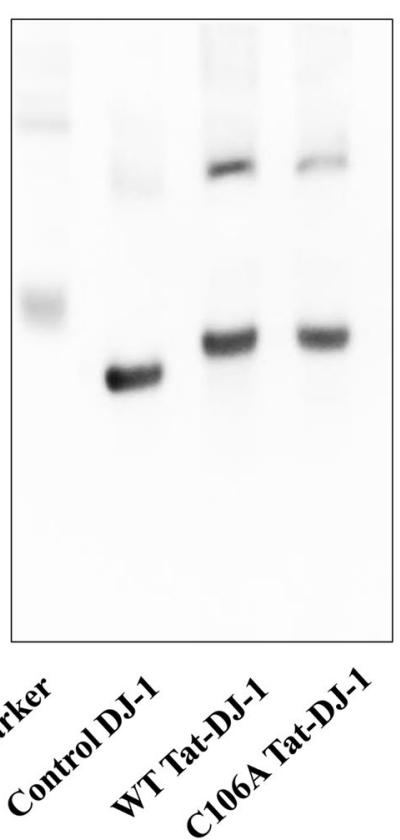

Fig. 1 Purification of WT and C106A Tat-DJ-1 protein. A schematic representation of the WT and C106A Tat-DJ-1 protein (a). Expressed and purified fusion proteins were analyzed by $12 \%$ SDS-PAGE (b) and subjected to Western blot analysis (c) with an anti-polyhistidine antibody a
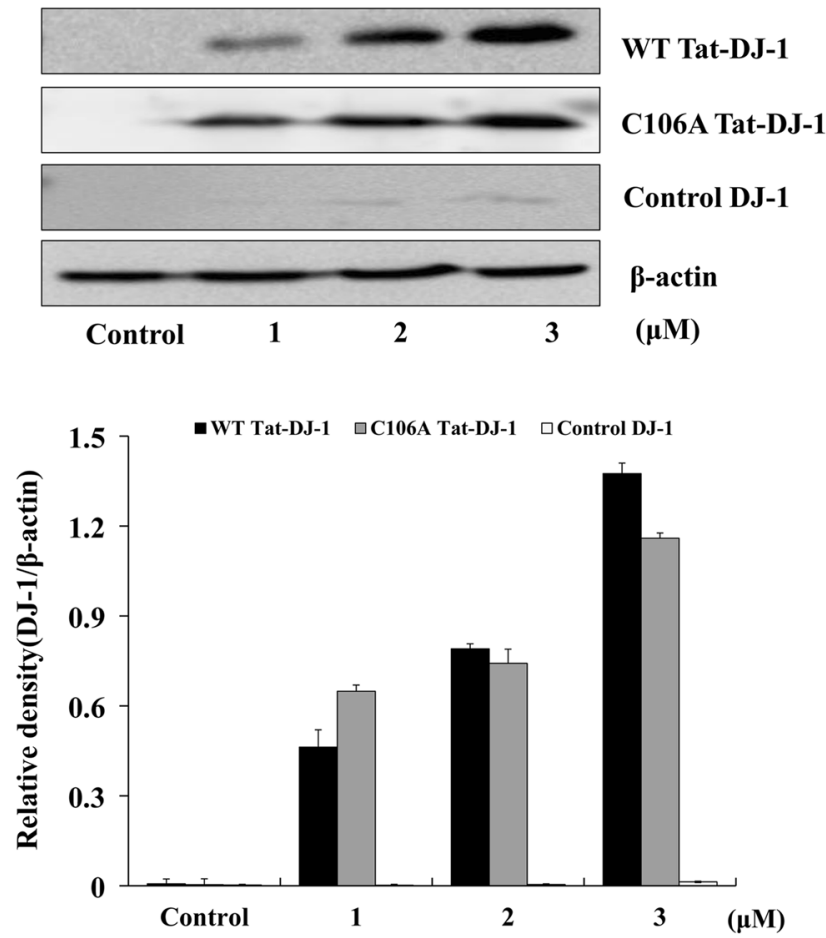

Fig. 2 Transduction of Tat-DJ-1 proteins into pancreatic RINm5F cells. WT and C106A Tat-DJ-1 and control DJ-1 proteins $(1-3 \mu \mathrm{M})$ were added to the RINm5F culture media for $1 \mathrm{~h}(\mathbf{a})$. WT and C106A Tat-DJ-1 and control DJ-1 proteins $(3 \mu \mathrm{M})$ were added to the RINm5F b
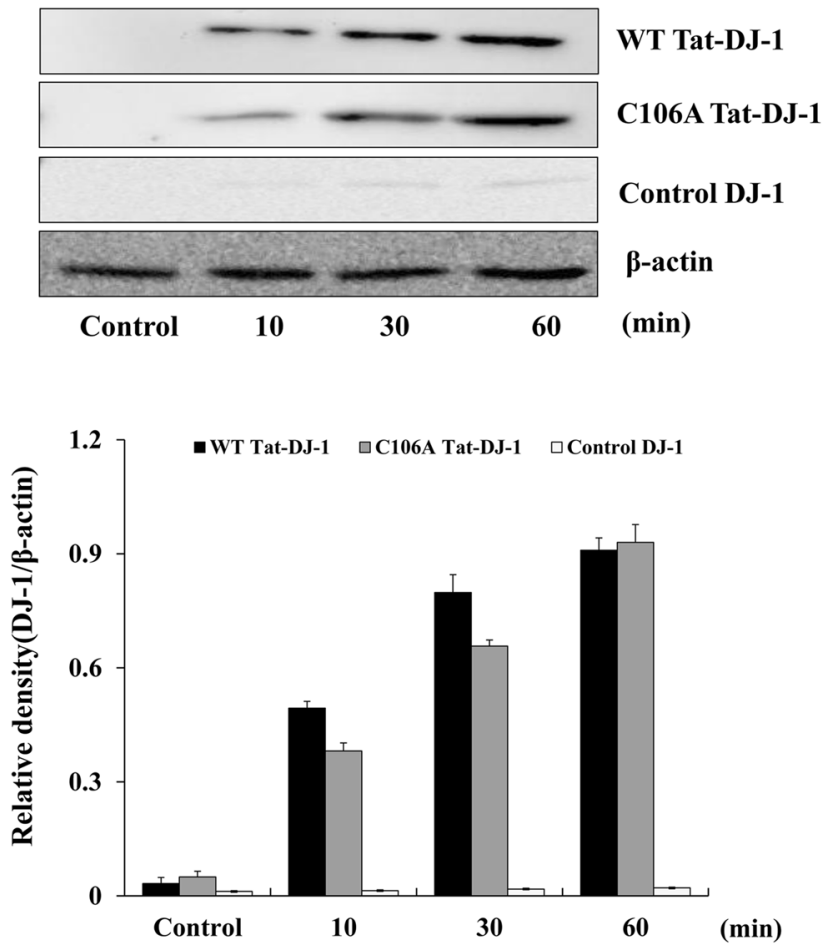

culture media for 10-60 min (b). Then, transduced Tat-DJ-1 protein levels were determined by Western blotting using an anti-polyhistidine antibody. The band intensities were measured by a densitometer 
a

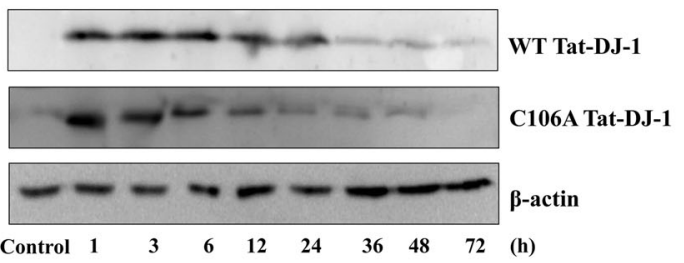

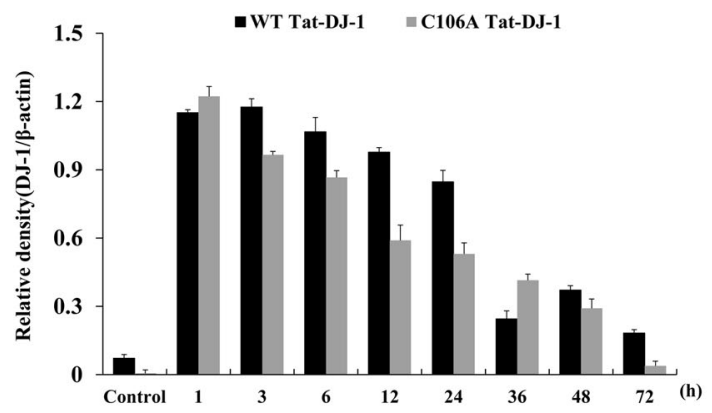

b

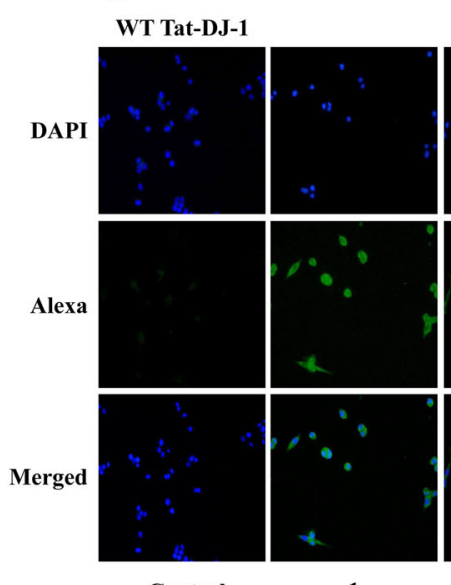

Control

c

C106A Tat-DJ-1

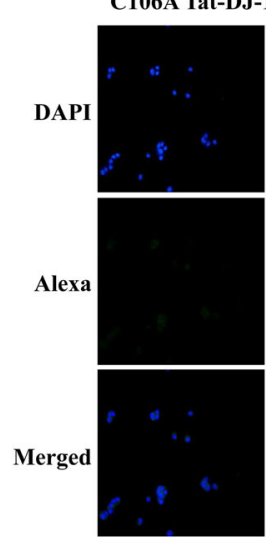

Control

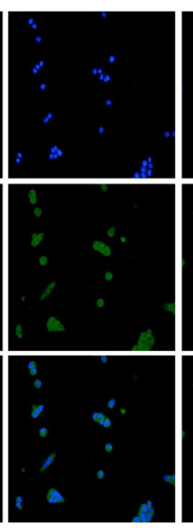

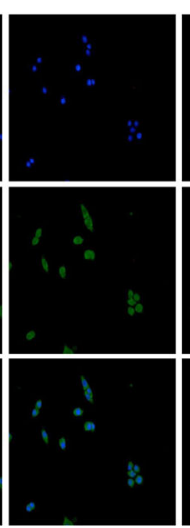

3

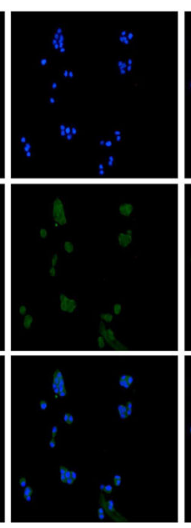

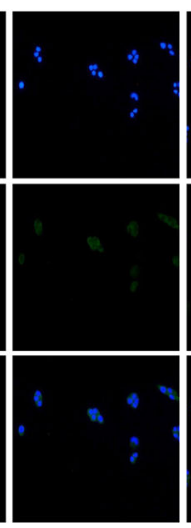

12

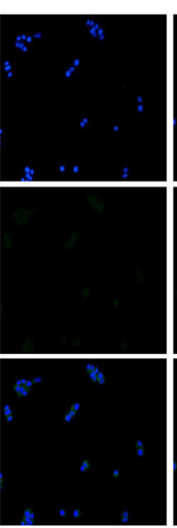

24

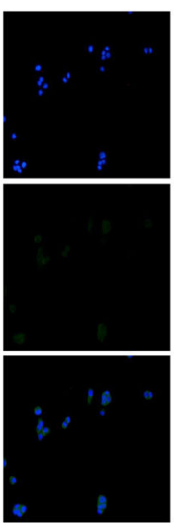

36

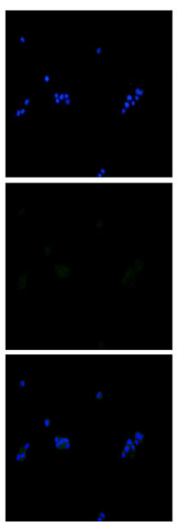

48

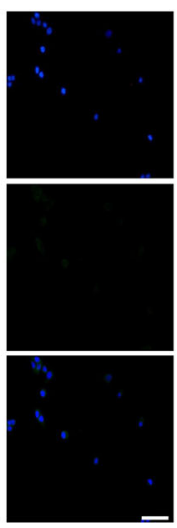

72 (h)

Fig. 3 Stability of transduced WT and C106A Tat-DJ-1 proteins into pancreatic RINm5F cells. RINm5F cells pretreated with $3 \mu \mathrm{M}$ WT and C106A Tat-DJ-1 proteins incubated for $1-72 \mathrm{~h}$, and analyzed by

studies have demonstrated that overexpression of DJ-1 protein in MIN6 cells caused by DJ-1 gene transfection significantly increased cell survival in a dose-dependent manner in the $\mathrm{H}_{2} \mathrm{O}_{2}$-induced cells. In contrast, knockdown of DJ-1 in the cells by the small interfering RNA markedly reduced cell survival under same experimental conditions (Inberg and Linial, 2010). Other reports have shown that DJ-1 protein significantly protected against STZ-induced or cytokine-
Western blotting and band intensity was measured by densitometer (a) and by fluorescence microscopy $(\mathbf{b}-\mathbf{c})$. Scale bar $=20 \mu \mathrm{m}$

induced pancreatic $\beta$-cell death in DJ-1 knockout mice, leading the authors to suggest that the DJ-1 is required to protect against oxidative stress including STZ and cytokine-induced $\beta$-cell death (Inberg and Linial, 2010; Jain et al., 2015).

The effects of Tat-DJ-1 protein against oxidative stressinduced insulin secretion levels, intracellular ROS production, and DNA fragmentation were also explored. As shown in Fig. 5, insulin secretion levels in $\mathrm{H}_{2} \mathrm{O}_{2}$ exposed RINm5F cells 
a

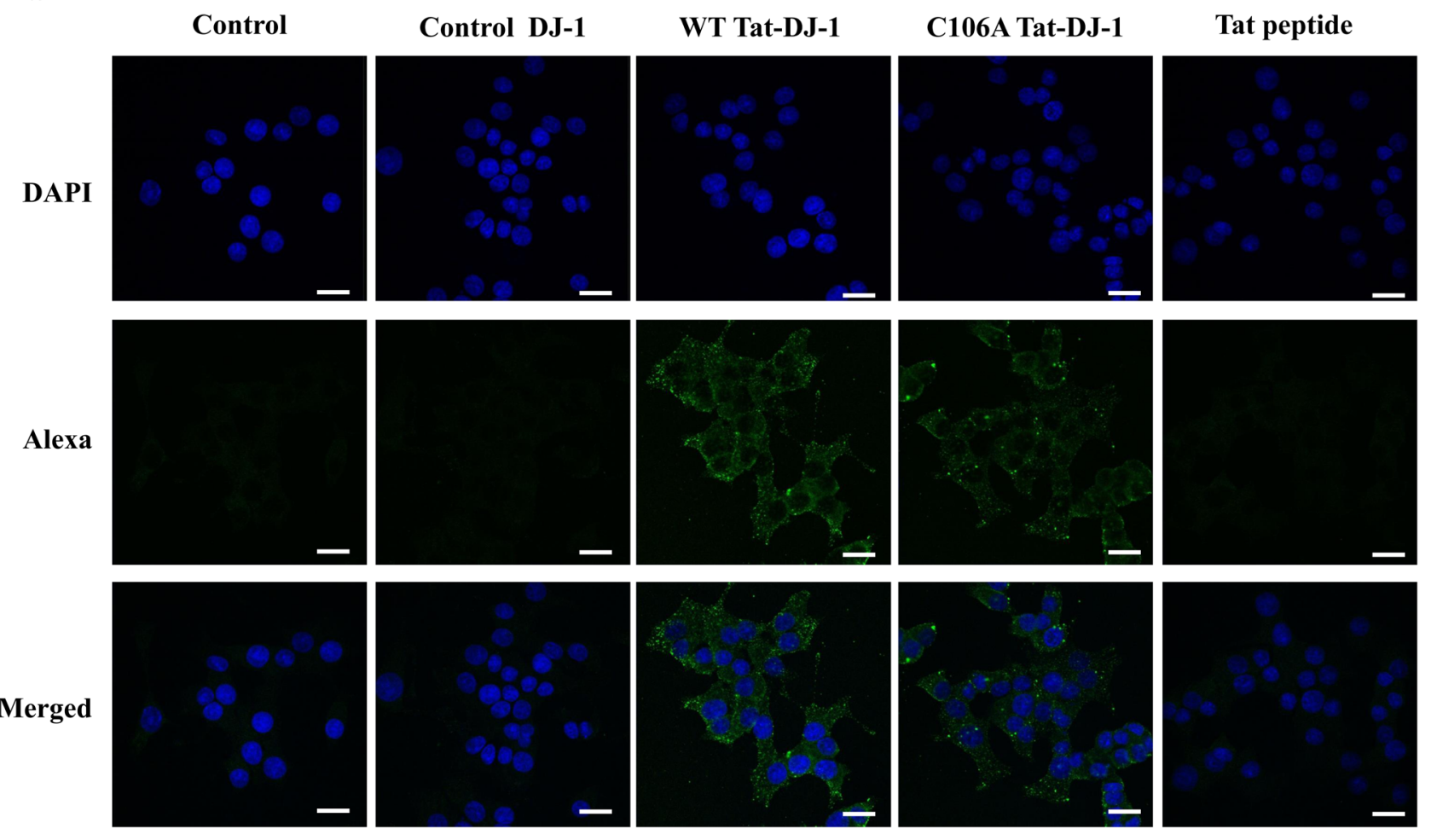

b

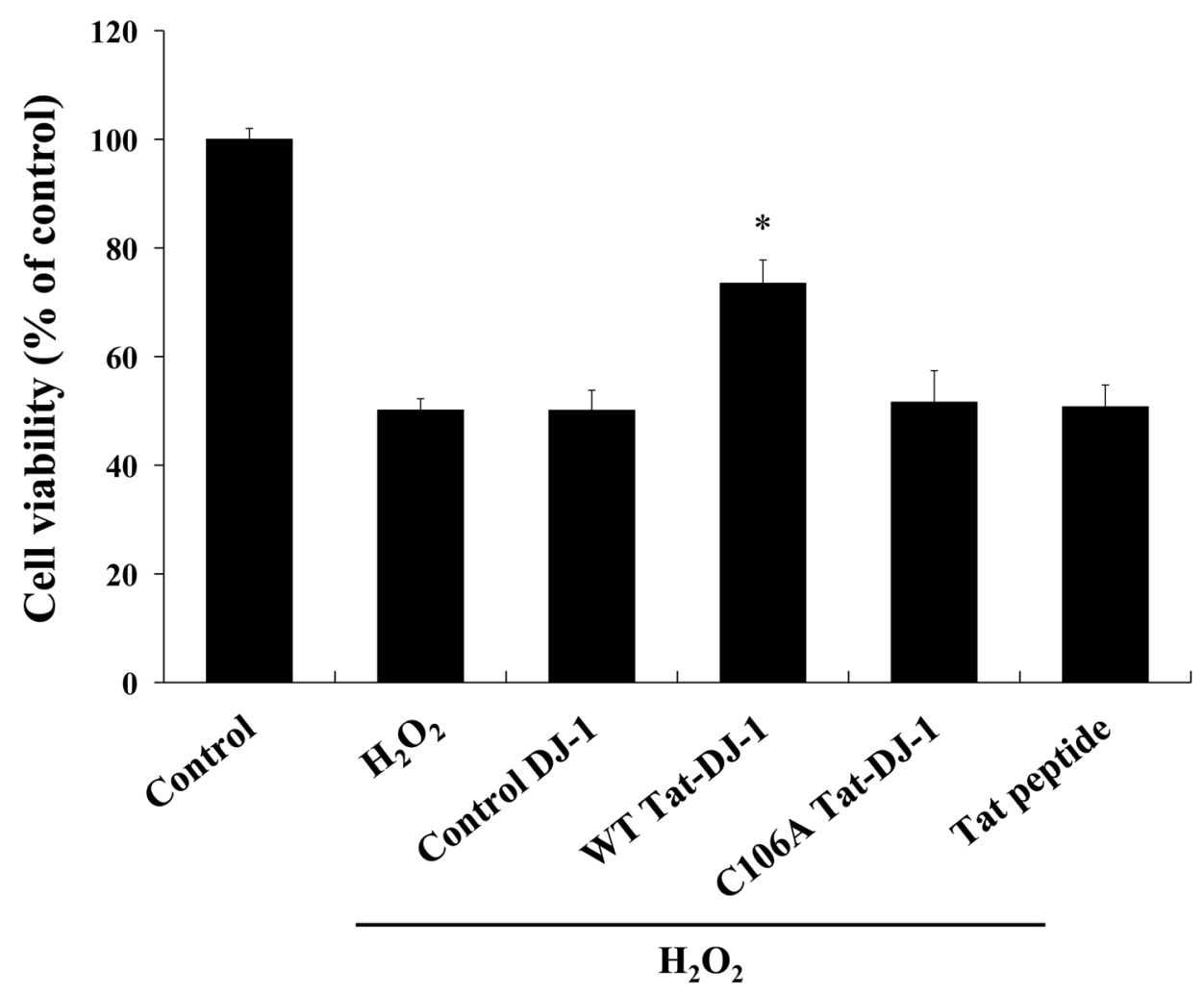

Fig. 4 Effects of transduced WT and C106A Tat-DJ-1 protein against oxidative stress-induced RINm5F cell death. The distribution of transduced Tat-DJ-1 into RINm5F cells was observed by fluorescence microscopy (a). Scale bar $=20 \mu \mathrm{m} . \mathrm{H}_{2} \mathrm{O}_{2}(0.3 \mathrm{mM})$ was added to
RINm5F cells pretreated with WT and C106A Tat-DJ-1 $(3 \mu \mathrm{M})$ for $1 \mathrm{~h}$. Cell viabilities were estimated using a colorimetric assay using MTT (b). ${ }^{*} P<0.05$, compared with $\mathrm{H}_{2} \mathrm{O}_{2}$-treated cells 
a

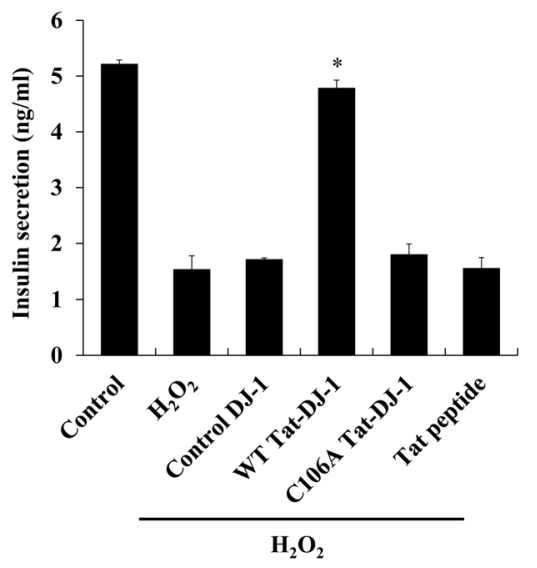

b

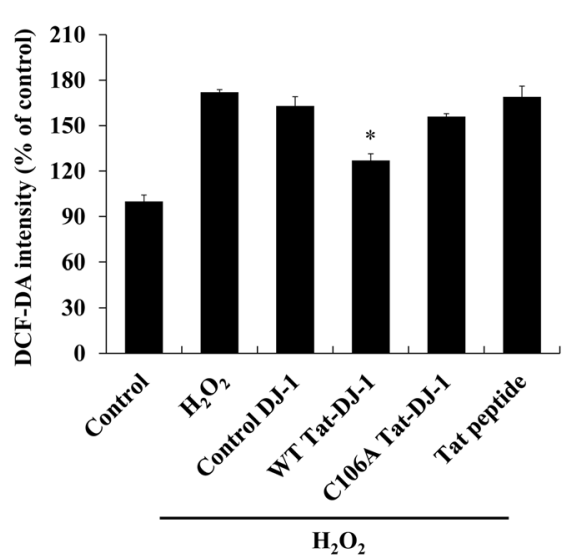

c

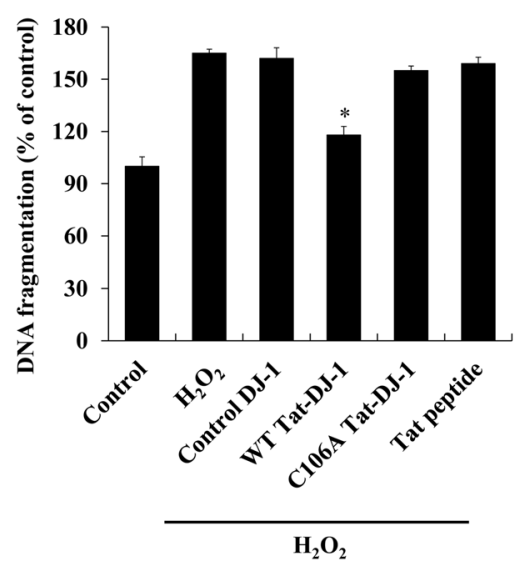

Fig. 5 Effects of WT and C106A Tat-DJ-1 protein against oxidative stress-induced insulin secretion, ROS generation, and DNA fragmentation in RINm5F cells. $\mathrm{H}_{2} \mathrm{O}_{2}(0.3 \mathrm{mM})$ was added to RINm5F cells pretreated with WT and C106A Tat-DJ-1 $(3 \mu \mathrm{M})$ for $1 \mathrm{~h}$. Insulin secretion levels (a), intracellular ROS levels (b), and DNA fragmentation (c) were determined. ${ }^{*} P<0.05$, compared with $\mathrm{H}_{2} \mathrm{O}_{2}$-treated cells were reduced in comparison to those of control cells; however, when the cells were treated with WT Tat-DJ-1 protein, the insulin secretion levels were markedly increased. Moreover, intracellular ROS production and DNA fragmentation were markedly increased in the cells treated with $\mathrm{H}_{2} \mathrm{O}_{2}$ only. Compared to cells treated with the $\mathrm{H}_{2} \mathrm{O}_{2}$ alone, cells treated with WT Tat-DJ-1 protein showed significantly reduced intracellular ROS production and DNA fragmentation. In contrast, C106A Tat-DJ-1 and control DJ-1 protein did not show any protective effects against oxidative stress-induced insulin secretion, intracellular ROS production, and DNA fragmentation. Taken together our results indicate that WT Tat-DJ-1 protein inhibits oxidative stress-induced cell death and plays an antioxidant role in cells. However, C106A TatDJ-1 protein lost its antioxidant function under oxidative stress conditions. Consistent with our results, other studies have demonstrated that Cys-106 mutations, including C106A, abolish the antioxidant functions of DJ-1 protein and suggest that Cys-106 residues in DJ-1 protein is of critical importance to the central redox site for DJ-1 function as a cytoprotective protein against oxidative stress (Blackinton et al., 2009; Waak et al., 2009). In addition, several studies have demonstrated that WT DJ-1 protein protected against oxidative stressinduced neuronal cell death by reducing intracellular ROS levels (Yanagisawa et al., 2008; Yanagida et al., 2009).

$\mathrm{NF}-\kappa \mathrm{B}$, which is known as a transcription factor, plays a critical role in regulating the expression of a number of genes and involves the various diseases, including inflammation, tumor development, and cellular proliferation and survival (Sun and Zhang, 2007; Liu et al., 2008; Vallabhapurapu and Karin, 2009; Mitchell et al., 2016). In resting cells, NF- $\kappa \mathrm{B}$ consists of p65 and p50 proteins and binds to $\mathrm{I} \kappa \mathrm{B} \alpha$ protein in the cytoplasm. By various external stimuli, $\mathrm{I} \kappa \mathrm{B} \alpha$ changed to phosphorylated $\mathrm{I} \kappa \mathrm{B} \alpha$ and subsequently dissociated from complex of $\mathrm{NF}-\kappa \mathrm{B} / \mathrm{I} \kappa \mathrm{B} \alpha$ and then $\mathrm{NF}-\kappa \mathrm{B}$ translocated from the cytosol to the nucleus (Kim et al., 2016; Mitchell et al., 2016; Yang and Wang, 2016).

Mitogen-activated protein kinases (MAPKs) consist of p38, c-Jun $\mathrm{NH}_{2}$-termimal kinase (JNK), and extracellular signal-regulated kinase (ERK), and associates with cell proliferation, differentiation, survival, and cell death (McCubrey et al., 2006; Dhillon et al., 2007; Kim and Choi, 2010). Since activated MAPK signaling pathways induced by various cellular stress has been associated with various human diseases, NF- $\kappa \mathrm{B}$ and MAPK singling pathways are considered as targets for the development of therapeutic drugs (Cowan and Storey, 2003; Kim and Choi, 2010; Mitchell et al., 2016; Yang and Wang, 2016). Therefore, we examined the effects of Tat-DJ-1 proteins against oxidative stress-induced MAPK activation. Figure 6 demonstrates the marked increase of phosphorylated p38, JNK, and ERK expression levels in $\mathrm{H}_{2} \mathrm{O}_{2}$-treated cells. However, the levels were drastically reduced in WT Tat-DJ-1-treated cells, while the levels were unchanged in C106A Tat-DJ-1 and control DJ-1 proteintreated cells compared to cells exposed to $\mathrm{H}_{2} \mathrm{O}_{2}$ only.

Next, we examined the effects of Tat-DJ-1 protein on oxidative stress-induced $\mathrm{NF}-\kappa \mathrm{B}$ activation by Western blotting. Our results show that phosphorylated p65 and $\mathrm{I} \kappa \mathrm{B} \alpha$ expression levels were increased by $\mathrm{H}_{2} \mathrm{O}_{2}$. In contrast, transduced WT Tat-DJ-1 protein significantly decreased phosphorylated p65 and $\mathrm{I} \kappa \mathrm{B} \alpha$ expression levels. The expression levels of phosphorylated p65 and $\mathrm{I} \kappa \mathrm{B} \alpha$ were unaltered in C106A Tat-DJ-1 and control DJ-1 proteintreated cells compared to $\mathrm{H}_{2} \mathrm{O}_{2}$-treated cells (Fig. 7). The combined results of our experiments suggest that WT Tat-DJ-1 protein, and not C106A Tat-DJ-1 protein, inhibit oxidative stress-induced pancreatic RINm5F cell death via regulation of $\mathrm{NF}-\kappa \mathrm{B}$ and MAPK activation. 


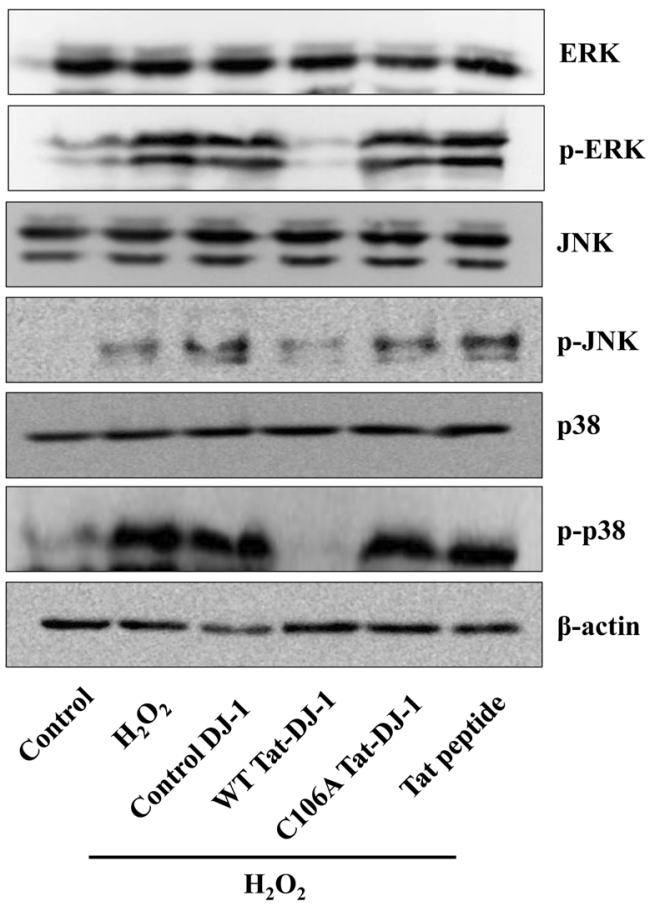

Fig. 6 Effects of WT and C106A Tat-DJ-1 protein against oxidative stress-induced MAPK activation. RINm5F cells were treated with WT and C106A Tat-DJ-1 $(3 \mu \mathrm{M})$ for $1 \mathrm{~h}$. MAPKs activation was detected

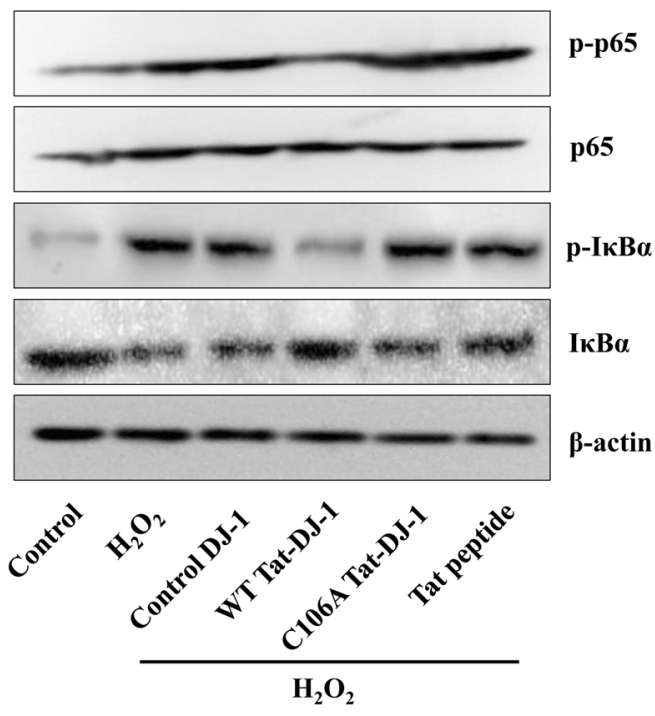

Fig. 7 Effects of WT and C106A Tat-DJ-1 protein against oxidative stress-induced NF- $\mathrm{BB}$ activation. RINm5F cells were treated with WT and C106A Tat-DJ-1 $(3 \mu \mathrm{M})$ for $1 \mathrm{~h}$. NF- $\mathrm{\kappa B}$ activation was detected

\section{Conclusions}

We have shown that WT Tat-DJ-1 protein transduced into RINm5F cells and markedly inhibited oxidative stressinduced cell death through a reduction in ROS generation

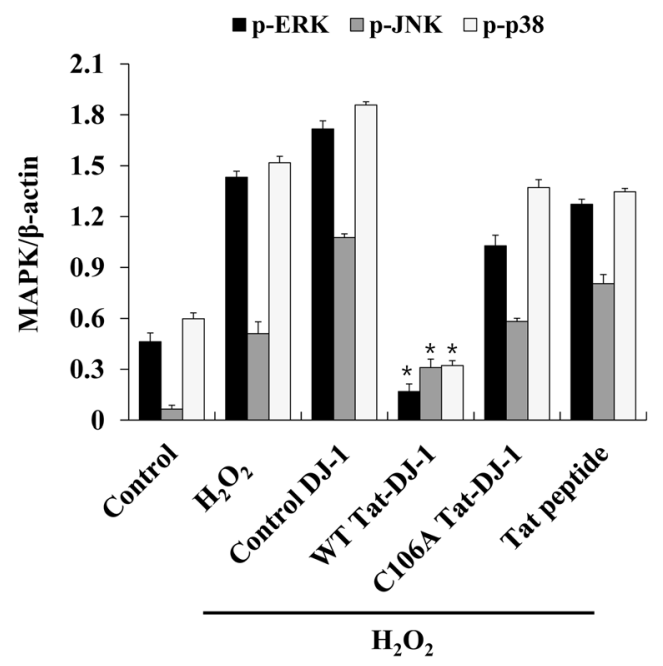

using Western blot analysis and band intensity was measured by densitometer. ${ }^{*} P<0.05$, compared with $\mathrm{H}_{2} \mathrm{O}_{2}$-treated cells

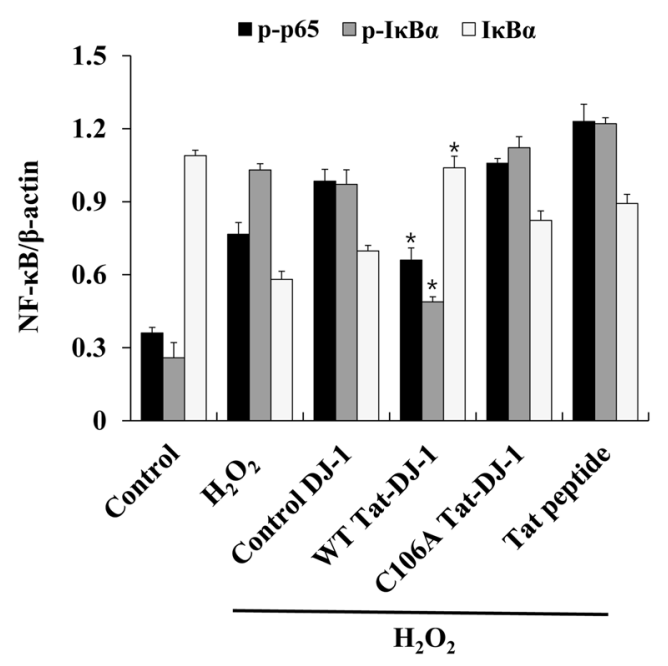

using Western blot analysis and band intensity was measured by densitometer. ${ }^{*} P<0.05$, compared with $\mathrm{H}_{2} \mathrm{O}_{2}$-treated cells

and DNA fragmentation, as well as the activation of NF- $\mathrm{KB}$ and MAPK. In contrast, C106A Tat-DJ-1 and control DJ-1 protein did not show any protective effects against oxidative stress-induced cell death. Although further studies are needed in vivo, our results suggest a potential role for WT 
Tat-DJ-1 protein as a therapeutic agent for oxidative stressinduced diseases including diabetes mellitus.

\section{Materials and methods}

\section{Materials}

Primary, secondary, and $\beta$-actin antibodies were obtained from Cell Signaling Technology (Beverly, MA, USA) and Santa Cruz Biotechnology (Santa Cruz, CA, USA). Mutant C106A DJ-1 cDNA was obtained from Dr. Eun-Hye Joe (Ajou University). RINm5F cells, a pancreatic $\beta$-cell line, were purchased from the ATCC (Manassas, VA, USA). Tat peptides were purchased from PEPTRON (Daejeon, Korea). All other agents were of the highest grade available unless otherwise stated.

\section{Purification and transduction of Tat-DJ-1 proteins into RINm5F cells}

A Tat expression vector was prepared as described previously (Kim et al., 2013). After human DJ-1 cDNA were amplified by polymerase chain reaction using the sense primer 5'-CTCGAGGCTTCCAAAAGAGC-3' and the antisense primer 5'-GGATCCCTAGTCTTTAAGAA-3', the product was cloned in a TA-cloning vector and ligated into the Tat expression vector. Tat-DJ-1 proteins were cultured in $E$. coli and overexpressed with Isopropyl-b-Dthiogalactoside (IPTG). Then the cells were lysed and purified using Ni-NTA affinity and PD-10 column chromatography. Purified protein concentrations were estimated by the Bradford assay (Bradford, 1976).

RINm5F cells were grown in RPMI1640 medium containing $10 \%$ fetal bovine serum and antibiotics $(100 \mu \mathrm{g} / \mathrm{ml}$ streptomycin, $100 \mathrm{U} / \mathrm{ml}$ penicillin) at $37^{\circ} \mathrm{C}$ in a humidity chamber with $5 \% \mathrm{CO}_{2}$ and $95 \%$ air. To examine Tat-DJ-1 protein transduction into RINm5F cells, the cells were treated with Tat-DJ-1 protein $(1-3 \mu \mathrm{M})$ for $1 \mathrm{~h}$ or treated with Tat-DJ-1 protein $(3 \mu \mathrm{M})$ for various times (10-60 min). The cells were then treated with trypsin-EDTA and washed with phosphate-buffered saline (PBS) and harvested for the preparation of cell extracts to perform Western blot analysis.

\section{Western blot analysis}

Equal amounts of proteins were separated with $12 \%$ SDSPAGE and transferred to nitrocellulose membrane. The membrane was blocked with $5 \%$ nonfat dry milk in trisbuffered saline including Tween 20 (TBST) buffer $(25 \mathrm{mM}$ Tris- $\mathrm{HCl}, 140 \mathrm{mM} \mathrm{NaCl}, 0.1 \%$ Tween 20, pH 7.5) for $1 \mathrm{~h}$ and incubated with the primary and secondary antibodies at room temperature. The indicated protein bands were detected using chemiluminescent reagents (Amersham, Franklin Lakes, NJ, USA) (Kim et al., 2013; Kim et al., 2015b).

\section{Cell viability assay}

To determine whether transduced Tat-DJ-1 protein has a protective effect against oxidative stress-induced cell death, RINm5F cells were treated with Tat-DJ-1 proteins $(3 \mu \mathrm{M})$ for $1 \mathrm{~h}$ and $\mathrm{H}_{2} \mathrm{O}_{2}(0.3 \mathrm{mM})$ was added to the culture medium for $12 \mathrm{~h}$. Then, cell viability was analyzed by a colorimetric assay using MTT as described in previous studies (Seo et al., 2015). Cell viability was measured at $570 \mathrm{~nm}$ using an enzyme-linked immunosorbent assay (ELISA) microplate reader (Labsystems Multiskan MCC/340) and cell viability was defined as the percentage of untreated control cells.

\section{Insulin secretion measurement}

We examined whether Tat-DJ-1 protein ameliorates insulin secretion in RINm5F cells under oxidative stress. The cells were treated with Tat-DJ-1 proteins $(3 \mu \mathrm{M})$ for $1 \mathrm{~h}$ and $\mathrm{H}_{2} \mathrm{O}_{2}(0.3 \mathrm{mM})$ was added to the culture medium for $12 \mathrm{~h}$. Then, insulin secretion levels were measured using an insulin ELISA kit (Shibayagi Co. Ltd, Japan).

\section{ROS measurements}

Intracellular ROS levels were measured using a ROS detection kit according to the manufacturer's instructions (Kim et al., 2015b; Shehzad et al., 2015). RINm5F cells were pretreated with Tat-DJ-1 protein $(3 \mu \mathrm{M})$ for $1 \mathrm{~h}$ and treated with $\mathrm{H}_{2} \mathrm{O}_{2}(0.3 \mathrm{mM})$ for $30 \mathrm{~min}$. Then, the cells were washed twice with PBS and fluorescence intensity was measured at $485 \mathrm{~nm}$ excitation and $538 \mathrm{~nm}$ emission using a Fluoroskan ELISA plate reader (Labsystems Oy, Helsinki, Finland).

\section{Measurement of DNA damage}

RINm5F cells were cultured in the presence or absence of Tat-DJ-1 proteins $(3 \mu \mathrm{M})$ for $1 \mathrm{~h}$ and the cells were incubated with $\mathrm{H}_{2} \mathrm{O}_{2}(0.3 \mathrm{mM})$ for $6 \mathrm{~h}$. Then, DNA damage was assessed using a Cell Death Detection kit (Roche Applied Science, Basel, Switzerland) as previously described (Kim et al., 2015b). Fluorescence-positive cells were counted by phase-contrast microscopy $(\times 200$ magnification $)$ of the cells. 


\section{Analysis of NF-אB and MAPK activation}

RINm5F cells were cultured in the presence or absence of Tat-DJ-1 proteins $(3 \mu \mathrm{M})$ for $1 \mathrm{~h}$ and the cells were incubated in $\mathrm{H}_{2} \mathrm{O}_{2}(0.3 \mathrm{mM})$ for $4 \mathrm{~h}$. The activation of MAPK and NF- $\mathrm{KB}$ were analyzed by Western blotting using indicated specific antibodies. The expression bands were quantified using Image $\mathbf{J}$ software (NIH, Bethesda, MD, USA).

\section{Statistical analysis}

Data represent as means \pm standard error of the mean. Comparison between each groups were performed using one-way analysis of variance followed by the Dunnett's test using GraphPad Prism 5 (GraphPad Software Inc., La Jolla, CA, USA). Statistical significance was set at $P<0.05$.

Acknowledgments This work was supported through the National Research Foundation of Korea funded by the Ministry of Education (2014R1A1A4A01008026) and it was also supported by a Priority Research Centers Program grant (NRF-2009-0093812) through the National Research Foundation of Korea funded by the Ministry of Science, ICT \& Future Planning in the Republic Korea.

\section{Compliance with ethical standards}

Conflict of interest The authors declare that they have no conflict of interest.

\section{References}

Aleyasin H, Rousseaux MW, Phillips M, Kim RH, Bland RJ, Callaghan S, Slack RS, During MJ, Mak TW, Park DS (2007) The Parkinson's disease gene DJ-1 is also a key regulator of stroke induced damage. Proc Natl Acad Sci USA 104:18748-18753

Blackinton J, Lakshminarasimhan M, Thomas KJ, Ahmad R, Greggio E, Raza AS, Cookson MR, Wilson MA (2009) Formation of a stabilized cysteine sulfinic acid is critical for the mitochondrial function of the parkinsonism protein DJ-1. J Biol Chem 284:6476-6485

Bonifati V, Rizzu P, van Baren MJ, Schaap O, Breedveld GJ, Krieger E, Dekker MC, Squitieri F, Ibanez P, Joosse M, van Dongen JW, Vanacore N, van Swieten JC, Brice A, Meco G, van Duijn CM, Oostra BA, Heutink P (2003) Mutations in the DJ-1 gene associated with autosomal recessive early-onset parkinsonism. Science 299:256-259

Bradford MA (1976) Rapid and sensitive method for the quantitation of microgram quantities utilizing the principle of protein-dye binding. Anal Biochem 72:248-254

Cowan KJ, Storey KB (2003) Mitogen-activated protein kinases: signaling pathways functioning in cellular responses to environmental stress. J Exp Biol 206:1107-1115

Dhillon AS, Hagan S, Rath O, Kolch W (2007) MAP kinase signaling pathways in cancer. Oncogene 26:3279-3290

Dietz GP (2010) Cell-penetrating peptide technology to deliver chaperones and associated factors in diseases and basic research. Curr Pharm Biotechnol 11:167-174

Fawell S, Seery J, Daikh Y, Moore C, Chen LL, Pepinsky B, Barsoum J (1994) TAT mediated delivery of heterologous proteins into cells. Proc Natl Acad Sci USA 91:664-668
Hohmeier HE, Thigpen A, Tran VV, Davis R, Newgard CB (1998) Stable expression of manganese superoxide dismutase (MnSOD) in insulinoma cells prevents IL-1beta-induced cytotoxicity and reduces nitric oxide production. J Clin Invest 101:1811-1820

Inberg A, Linial M (2010) Protection of pancreatic $\beta$-cells from various stress conditions is mediated by DJ-1. J Biol Chem 285:25686-25698

Jain D, Weber G, Eberhard D, Mehana AE, Eglinger J, Welters A, Bartosinska B, Jeruschke K, Weiss J, Path G, Ariga H, Seufert J, Lammert E (2015) DJ-1 protects pancreatic beta cells from cytokineand streptozotocin-mediated cell death. PLoS ONE e10:e0138535

Jay SM, Lee RT (2013) Protein engineering for cardiovascular therapeutics: untapped potential for cardiac repair. Circ Res 113:933-943

Kim DW, Lee SH, Shin MJ, Kim K, Ku SK, Youn JK, Cho SB, Park JH, Lee CH, Son O, Sohn EJ, Cho SW, Park JH, Kim HA, Han KH, Park J, Eum WS, Choi SY (2015a) PEP-1-FK506BP inhibits alkali burn-induced corneal inflammation on the rat model of corneal alkali injury. BMB Rep 48:618-623

Kim EK, Choi EJ (2010) Pathological roles of MAPK signaling pathways in human diseases. Biochim Biolphys Acta 1802: 396-405

Kim H, Youn GS, An SY, Kwon HY, Choi SY, Park J (2016) 2.3Dimethoxy-2'-hydroxychalcone ameliorates TNF- $\alpha$-induced ICAM-1 expression and subsequent monocyte adhesiveness via NF-kappaB inhibition and HO-1 induction in HaCaT cells. BMB Rep 49:57-62

Kim MJ, Kim DW, Lee BR, Shin MJ, Kim YN, Eom SA, Park BJ, Cho YS, Han KH, Park J, Hwang HS, Eum WS, Choi SY (2013) Transduced Tat-glyoxalase protein attenuates streptozotocininduced diabetes in a mouse model. Biochem Biophys Res Commun 430:294-300

Kim MJ, Park M, Kim DW, Shim MJ, Son O, Jo HS, Yeo HJ, Cho SB, Park JH, Lee CH, Kim DS, Kwon OS, Kim J, Han KH, Park J, Eum WS, Choi SY (2015b) Transduced PEP-1-PON1 proteins regulate microglial activation and dopaminergic neuronal death in a Parkinson's disease model. Biomaterials 64:45-56

Kinumi T, Kimata J, Taira T, Ariga H, Niki E (2004) Cysteine-106 of DJ-1 is the most sensitive cysteine residue to hydrogen peroxidemediated oxidation in vivo in human umbilical vein endothelial cells. Biochem Biophys Res Commun 317:722-728

Koren E, Torchilin VP (2012) Cell-penetrating peptides: breaking through to the other side. Trends Mol Med 18:385-393

Kubo E, Fatma N, Akagi Y, Beier DR, Singh SP, Singh DP (2008) TAT-mediated PRDX6 protein transduction protects against eye lens epithelial cell death and delays lens opacity. J Physiol Cell Physiol 294:C842-C855

Lee SJ, Kang HK, Song DK, Eum WS, Park J, Choi SY, Kwon HY (2015) Transduced PEP-1-heme oxygenase-1 into insulin-producing INS-1 cells protects them against cytokine-induced cell death. Biochem Biophys Res Commun 461:549-554

Lenzen S, Drinkgern J, Tiedge M (1996) Low antioxidant enzyme gene expression in pancreatic islets compared with various other mouse tissues. Free Radic Biol Med 20:463-466

Liu X, Togo S, Al-Mugotir M, Kim H, Fang QH, Kobayashi T, Wang XQ, Mao L, Bitterman P, Rennard S (2008) NF-kappaB mediates the survival of human bronchial epithelial cells exposed to cigarette smoke extract. Respir Res 9:66

McCubrey JA, Lahair MM, Franklin RA (2006) Reactive oxygen species-induced activation of the MAP kinase signaling pathways. Antioxid Redox Signal 8:1775-1789

Mitchell S, Vargas J, Hoffmann A (2016) Signaling via the NFkB system. WIREs Syst Biol Med 8:227-241

Seo WY, Youn GS, Choi SY, Park J (2015) Butein, a tetrahydroxychalcone, suppresses pro-inflammatory responses in HaCaT keratinocytes. BMB Rep 48:495-500 
Shehzad A, Lee J, Lee YS (2015) Autocrine prostaglandin E2 signaling promotes promonocytic leukemia cell survival via COX-2 expression and MAPK pathway. BMB Rep 48:109-114

Shendelman S, Jonason A, Martinat C, Leete T, Abeliovich A (2004) DJ-1 is a redox-dependent molecular chaperone that inhibits alpha-synuclein aggregate formation. PLoS Biol 2:1764-1773

Suarez-Pinzon WL, Szabo C, Rabinovitch A (1997) Development of autoimmune diabetes in NOD mice is associated with the formation of peroxynitrite in pancreatic islet beta-cells. Diabetes 46:907-911

Sun XF, Zhang H (2007) NFKB and NFKBI polymorphisms in relation to susceptibility of tumour and other diseases. Histol Histopathol 22:1387-1398

Tabatabaie T, Vasquez-Weldon A, Moore DR, Kotake Y (2003) Free radicals and the pathogenesis of type 1 diabetes: $\beta$-cell cytokinemediated free radical generation via cyclooxygenase-2. Diabetes 52:1994-1999

Taira T, Saito Y, Niki T, Iguchi-Ariga SM, Takahashi K, Ariga H (2004) DJ-1 has a role in antioxidative stress to prevent cell death. EMBO Rep 5:213-218

Tiedge M, Lortz S, Munday R, Lenzen S (1998) Complementary action of antioxidant enzymes in the protection of bioengineered insulin-producing RINm5F cells against the toxicity of reactive oxygen species. Diabetes 47:1578-1585

Tiedge M, Lortz S, Munday R, Lenzen S (1999) Protection against the co-operative toxicity of nitric oxide and oxygen free radicals by overexpression of antioxidant enzymes in bioengineered insulinproducing RINm5F cells. Diabetologia 42:849-855
Van den Berg A, Dowdy SF (2011) Protein transduction domain delivery of therapeutic macromolecules. Curr Opin Biotechnol 22:888-893

Vallabhapurapu S, Karin M (2009) Regulation and function of NF-кB transcription factors in the immune system. Annu Rev Immunol 27:693-733

Waak J, Weber SS, Gorner K, Schall C, Ichijo H, Stehle T, Kahle PJ (2009) Oxidizable residues mediating protein stability and cytoprotective interaction of DJ-1 with apoptosis signal-regulating kinase 1. J Biol Chem 284:14245-14257

Wadia JS, Dowdy SF (2002) Protein transduction technology. Curr Opin Biotechnol 13:52-56

Yanagida T, Tsushima J, Kitamura Y, Yanagisawa D, Takata K, Shibaike T, Yamamoto A, Taniguchi T, Yasui H, Taira T, Morikawa S, Inubushi T, Tooyama I, Ariga H (2009) Oxidative stress induction of DJ-1 protein in reactive astrocytes scavenges free radicals and reduces cell injury. Oxid Med Cell Longev 2:36-42

Yanagisawa D, Kitamura Y, Inden M, Takata K, Taniguchi T, Morikawa S, Morita M, Inubushi T, Tooyama I, Taira T, Iguchi-Ariga SMM, Akaike A, Ariga H (2008) DJ-1 protects against neurodegeneration caused by focal cerebral ischemia and reperfusion in rats. J Cereb Blood Flow Metab 28:563-578

Yang Y, Wang JK (2016) The functional analysis of microRNAs involved in NF-KB signaling. Eur Rev Med Pharmacol Sci 20:1764-1774

Zhang Z, Huang L, Wu Q, Yang E, Zhang G, Sun H, Wang F (2014) A recombinant trans-membrane protein hMnSOD-R9 inhibits the proliferation of cervical cancer cells in vitro. Mol Cell Biochem 385:79-86 